\title{
Organ Accompaniments in England in the Sixteenth and Seventeenth Centuries
}

\section{W. H. Cummings F.S.A}

To cite this article: W. H. Cummings F.S.A (1899) Organ Accompaniments in England in the Sixteenth and Seventeenth Centuries, Proceedings of the Musical Association, 26:1, 193-212, DOI: $10.1093 / \mathrm{jrma} / 26.1 .193$

To link to this article: http://dx.doi.org/10.1093/jrma/26.1.193

\section{曲 Published online: 28 Jan 2009.}

\section{Submit your article to this journal $\sqsubset$}

Џ Article views: 4 
May 8, 1900.

\section{T. L. SOUTHGATE, Es\&., IN the Chair.}

\section{ORGAN ACCOMPANIMENTS IN ENGLAND IN \\ THE SIXTEENTH AND SEVENTEENTH CENTURIES.}

By W. H. Cummings, F.S.A.

A FEW preliminary observations are desirable respecting organs and organ music of the centuries prior to the sixteenth.

In the thirteenth century both the Greek and Latin clergy deemed the use of organs in churches profane, and it is matter of common knowledge that the organ remains excluded from the Greek Church to this day.

In the fourteenth century the keys of the organ were so large that the performer was termed a pulsator or smiter; you will not be surprised therefore to learn that the right mode of smiting the keys was with the closed fist. We are told* that the organ at Halberstadt, built in 1361 , had keys from two to four inches in width, with a space of two inches between some of them.

During the fifteenth century the keys were reduced in size, and fresh adaptations and contrivances were devised for facilitating the labours of the organist.

An organ erected during that century in the church of St. Egidien, in Brunswick, had keys about is inches wide, without any appreciable space between them. Each key had its name-letter inscribed on it, as F, G, A, H, \&c. Some of you are doubtless familiar with the engraving of a performing organist, depicted in Gaffurius' "'Theorica Musica," 1492 ; it would seem from that picture that the organist used both hands.

"Seidel, " Die Orgel und ihr Bau." Breslau, 1842. 
The facilities afforded for playing with fingers, instead of with the fists, would naturally necessitate some technical exercises specially devised for acquiring manual dexterity, and I now produce for inspection a MS. in the autograph of Adam Ileborgh, written by him when rector of the University of Stendall, in 1448. The title is-

\section{"Incipiunt præludia diversarum notarum secundum modernum modum}

subtiliter et diligenter collecta cum mensuris diversis hic infra annexis per fratrem Adam Ileborgh Anno Domini 1448 tempore sui rectoriatus in Stendall."

This is one of the earliest examples of organ music existing; it shows that the musicians of the fifteenth century found such a work indispensable, and all who have succeeded them have also recognised the want.

Ileborgh's MS. is on parchment, beautifully written, the music legible and readable, from a staff of eight lines, with the three clefs $F, C, G$.

In referring to the organ accompaniments of England in the sixteenth and seventeenth centuries I shall endeavour to elucidate truth; in doing so I shall have to speak very emphatically about certain erroneous statements which have appeared in print, and therefore in advance ask your indulgence if, in my enthusiasm for " truth," I am obliged to be uncompromising. On the 6th of May last year a letter appeared in Notes and Queries signed by one of our members, Mr. Davey, in which appeared the following sentence: "The ordinary use of the organ in the seventeenth century was to add brilliancy to the vocal music sung by the choir, and all possible embellishment by florid runs seems to have been employed. The Puritans objected to that style of sacred music, and so should we object if it were heard now. The result was a blind rage which led to the destruction of several cathedral organs." To this I ventured to reply, pointing to the publication of the "Musica Deo Sacra," by Tomkins, as one of the proofs to the contrary. On the 16th December Mr. Davey again appeared in print with a letter containing the following extraordinary statement: "I will discuss his (Mr. Cummings) denial of my assertion that the organ accompaniments used before the Civil War were of an absurdly florid character and justly objected to by the Puritans. I can point to the florid organ music preserved in the Mulliner MS. and the so-called virginal books; but still better evidence was adduced at an address on Cromwell and Music given by myself at Hampstead during the 
Cromwell tercentenary celebrations. The organist of the Chapel Royal was amongst the audience, and stated after. wards that he possessed an old printed organ score of the well-known Service in F, by Orlando Gibbons (organist to James I. and Charles I.), ' as played by Mr. Gibbons himself,' full of meaningless embellishments." This very precise and startling statement I felt quite sure was erroneous. I knew that the earliest printed copy of Gibbons's Service is that in Boyce's 'Cathedral Music,' published in 1760. I may here note that the words " as played by Mr. Gibbons himself" are given by Mr. Davey in inverted commas by way of emphasis. I therefore wrote to the organist of the Chapel Royal and asked the date of this wonderful "old printed score." Here is Dr. Creser's reply : "I did possess a curious, though not an old copy of Gibbons in F, with a figurative accompaniment, which to my mind would spoil the voice parts. It was printed privately by our dear friend Stainer." "Stainer will be able to give you the history of it. I imagine it was taken from an old MS., but that is all I know."

I then wrote to Sir John Stainer, and he was kind enough to send me the copy of the music, and also a note, part of which is as follows :-

"I send a very shabby copy of the Gibbons organ part. I have not seen the book (from which it was taken) for thirtyfive years; my memory may have faded, but it was, I should say, of about the date $1620-50$. It is a beautifully written MS. on six-line staves, large organ oblong. $L_{\text {think }}$ it contains the florid organ part of the whole Service, morning and evening." The copy is here for your inspection, it was printed by Sir John Stainer in 1864 , and is not a score, nor are there any vocal parts or guiding catch words, which, I believe, are invariably found in all Cathedral organ parts intended for accompaniment. As a matter of fact this arrangement was made to perform as an organ solo. I will cite the evidence of Dr. Edward J. Hopkins on this point. $\mathrm{He}$, from his long and intimate knowledge of organs and organ music, is an authority to whom all expert musicians will readily defer. He says :-

"It is necessary to notice the remarkable instrumental versions of some of the early church services and anthems, as those by Tallis, Gibbons, Amner, \&c., which are still to be met with in some of the old organ and other MS. music books. These versions are so full of runs, trills, beats, and matters of that kind, and so opposed in feeling to the quiet solidity and sober dignity of the vocal parts, that even if written by the same hand, which is scarcely credible, it is impossible that the former can ever have been designed to be used as an accompaniment to the latter." 
Dr. Hopkins then cites examples from the services of Tallis and Gibbons, which I need not trouble you with, and continues:-

"The headings or 'Indexings' of these versions stand as follows, and are very suggestive: ' Te Deum, Mr. Tallis in D, organ part varied'; 'Te Deum, Mr. Tallis, with variations for the organ; Gibbons in F, Morning, with variations'; - Te Deum, Mr. Orlando Gibbons, in F fa, ut, varied for the organ'; and so forth. There is little doubt, therefore, that the versions under notice were not intended as accompaniments at all, but were variations like the popular ' Transcriptions' of the present day and made for separate use, that use being doubtless as voluntaries. This explanation of the matter receives confirmation from the fact that a second old and more legitimate organ part of those services is still extant, for which no ostensible use would have existed if not to accompany the voices."

I wrote to Notes and Queries pointing out the facts I have now stated, hoping $\mathrm{Mr}$. Davey would recognise the grave error into which he had fallen; but he simply replied on February 17 last: "I am sorry I misdescribed the ancient organ music printed from the Magdalen College MS., but it nevertheless helps to prove my case. Specimens of these absurdly florid accompaniments are given in Grove's Dictionary of Music. The statement that they were not intended for practical use is a pure assumption, without a particle of evidence to support it. The simpler versions also existing, perhaps for less skilful executants, contain the outer parts with figures for the harmonies, which the organist filled up in the style he thought proper, plainly or ornately. Tomkins's 'Musica Deo Sacra' (1668) is also thus accompanied, if I recollect rightly."

I would have you note that the words " the statement that they were not intended for practical use," are Mr. Davey's own and not Dr. Hopkins's, who expressly says and explains that they were intended for practical use as voluntaries.

There is much more in Mr. Davey's letter which 1 shall deal with presently, and will now only quote one other paragraph of it :-

"As this discussion has lasted several months and is getting into technical matters, I suggest that it should be adjourned to one of the meetings of the Musical Association; in any case, I shall soon exhibit these specimens of organ accompaniments from the i6th century to the 18 th."

This is my excuse to the members of this Association for the somewhat unpleasant task I have undertaken to-day.

It will be well now to let you hear what Gibbons's accom. paniment really was, "As played by himself." The library of Christ Church, Oxford, contains several MSS. in Gibbons's 
handwriting, and amongst them a beautiful anthem composed for Archbishop Laud, president of St. Jolin's College, Oxford. It is set to the words "This is the record of John." The voice parts are for a male alto solo and chorus of five voicessoprano, two altos, tenor, and bass. The accompaniments are for a chest of viols and organ, the usual acconpaniments of the time for what were termed verse anthems. You will notice that the solo voice is accompanied by the strings alone, the parts being written in an engaging contrapuntal style. When the chorus enters the organ is added, and it, as well as the strings, always duplicate the voice parts. On this occasion the alto solo will be sung by a tenor, for you must remember that our pitch to-day is at least a whole tone lower than the Church pitch of Gibbons's time, and what was then intended for an alto voice can now more conveniently be sung by a tenor. (The anthen was then performed by students, vocalists, and instrumentalists, from the Guildhall School of Music.)

You will have observed that during each of the choruses in the anthem the strings and organ merely re-duplicated the voice parts-a custom, I believe, generally observed at the time-and, notwithstanding Mr. Davey's strong assertion to the contrary, that is precisely what we find in Tomkins's "Musica Deo Sacra." This book, printed in 1668 , must have been completed before 1656 , in which year Tomkins died. I did not think it necessary to bring all the vocal parts with me, but here is the organ part* and also one voice part for your inspection. As examples of the accompaniments used in Cathedrals, I produce MS. organ books from Chester Cathedral, + St. Paul's Cathedral. St. Jolnn's College, Cambridge, all of them containing seventeenth century work. ${ }_{+}$

In my preliminary remarks I referred to that remarkable MS. of Ileborgh (dated 1448 ) and hinted that the practice there presented of writing exercises for the organ was continued in after times-these exercise books, voluntary books, \&c., have sometimes been mistaken for accompaniments. I therefore produce two volumes of MS. organ music, one English, containing compositions dating from 1550 to 1654 , including voluntaries, lessons, fantasias, and

* The organ part is very scarce, and is not to be found in the British Museum.

† The Chester book contains compositions by John Hutchinson, organist of York in 1633; Orlando Gibbnns; Patrick of Westminster; Gyles of Windsor, 1595; Peter Stringer (autograph), organist of Chester, 166r ; Tallis; Thomas Tomkins; Albert Bryne, organist of St. Paul's, 1638; William Ottey; Michael Wise; Byrd; Eduard Tucker; Captain Cooke; and Thomas Fenell of Dublin, 1689.

* These books I have purchased from time to time, and cannot but express regret that they have not been preserved in the libraries of the churches to which they originally belonged. 
other pieces; on page 152 is a voluntary by Orlando Gibbons marked with the old English fingerings, 1 to 5. It contains music by $W$. Lawes, killed at the siege of Chester in ' 1645 ; Aylward of Norwich Cathedral, died 1669; Morley, died 1604; Gibbs, died in 1630; Bird, died 1623; and other composers, of Charles I.'s time. The other volume, of Italian organ music, is written in two staves of five and eight lines, with the three clefs $F, C$, and $G$. I believe it belongs wholly to the sixteenth century. The composers represented include Claudio da Corregio, Palestina, Adrian Vuillaert, Orlando di Lasso, Clemens non Papa, Ruggiero, and Cipriano del Rore.* I now want to say a word or two about the Mulliner and Redforde MSS. Mr. Davey wrote in Notes and Queries of February I7: "Mr. Cummings asserts that there are no organ accompaniments in the Mulliner MS., or that there is no organ accompaniment to the vocal music. All I can say is that I have copied several specimens of organ accompaniments from it; they are to Latin plain-songs. There are many more in Redford's MS. (Addit. MS. 29,996). By a strange coincidence, almost at the noment I read Mr. Cummings's reference to the Mulliner MS., I received a letter from Germany requesting a detailed account of its contents for Eitner's 'Quellenlexicon."

The Mulliner MS. I purchased at the sale of Dr. Rimbault's library in 1877 , and recognising what an important document it was in the history of English music, I handed it over to the British Museum for the exact sum I paid for it, namely $£^{82}$.

Having possessed the book, I ought to know something about it. Thomas Mulliner, by whom it was partly written, was master of the choristers of St. Paul's Cathedral in the sixteenth century, the dates of his birth and death are not known, but he was the teacher of several eminent musicians; Tallis was probably his pupil.

The book is a collection of motets, hymns, anthems, voluntaries, songs, \&c., by Tallis, Tye, Blytheman, Edwards, Farrant, Taverner, Johnson, Redford, Sheppard, Allwood, Shelbye, Newman, Nicholas, Carleton, some arranged for performance on the virginals and organ, and at the end are galliards in tablature for the lute, amongst them "The Queene of Scotts Galliard," per T. M. On the first fly leaf is the inscription "Sum liber Thomas Mullineri, Johanne Heywood teste." The binding of the book resembles the bindings of books of Henry the VIII.'s library, with ornamentations of the Tudor rose and the letters "H. R." It seems possible that it may have been compiled for the king or for his children.

- The names are spelt as in the MS. 
I will mention some of the pieces in the Mulliner volume:-

On fol. 16 there is one on a twelve-line staff, entitled " La Nonnette."

25 a Voluntary by Farrant.

30 " Fond youthe's a bubble," by Tallys, in score of two staves each of six lines; also an "In nomine," by Taverner, in two staves, the upper of five and the lower of seven lines.

" 70 " Rejoice in the Lord allwayes," in score of two staves, six lines each.

" 78 " $O$ the sylle man," by Edwards, in score.

" $\quad 80$ " In going to my naked bedde," by Edwards, in score.

" 94 " A Voluntary on the plain-song "Gloria tibi, trinitas." "

" 96 "Gloria tibi, trinitas," in score, the notation in notes of 0 d d.

" 1 Io "Like as the doleful dove," " fine quoth Master Tallys" (this has a note in Stafford Smith's handwriting, "Lent to Sir J. Hawkins, 1744")and we know that Hawkins printed this and several other excerpts from Mulliner's volume in his " History of Music."

" I18 is the commencement of several pages of music for the lute, in tablature, composed apparently by Mulliner; fol. 229 has his autograph signature, Thomas Mullyner.

This historic MS. was once the property of John Stafford Smith, an accomplished musical antiquary, and he lent it to Sir John Hawkins. Neither of these eminent authorities recognised any vocal music with accompaniments for the organ, and I have equally failed to do so.

Mr. Davey cited as another example of organ accompaniments the Redforde MS.* I was not familiar with that volume, and therefore considered it my duty to go to the British Museum and examine it. The volume is a thick folio-it is not paged, but numbered in folios, of which there are 219-that is, equal to $43^{8}$ pages; the contents are of a varied kind, music for virginals, music in score, fancies for 'vials in four parts' and in six parts-2 pavan by Gibbons, a duet for virginal and organ, exercises in counterpoint, lessons, \&c. ; but so far as I could see no vocal music with accompaniment for the organ. I may add that this volume was purchased for the Museum from John Bishop, of Cheltenham, who bought it of Joseph Warren, both of whom were keen musicians, well skilled in early English

* Add. MS. 29,996, Brit. Mus. 
music, particularly church music; both edited various pubhications of ecclesiastical nusic, but neither of them appears to have discovered any organ accompaniments in the Redforde volume. Some of the contents of the Redforde book are:-

Fol. 19 an exercise in three parts on a great score of twelve lines with three clefs, F, C, G.

" 29 Deus creator, "made by Phellppe Apprys of Saint Poulles in London."

" 35 Precatus est, in score of twelve lines, with three clefs, in handwriting of Redforde, who has subscribed at the end "Laus sit omnipotente Deo, Quod Master Johne Redforde."

" III has the note "These following are all in the compass of the hand, and so most fit to be played with ease"--the music is in score. I copied the initial bars and have identified them as a four-part song published by Byrd in 1589 to the words "I love a boy." I have brought a copy with me.

" 122 Anthem, " $O$ all ye nations," four parts in score, with words; followed by "April is in my mistress' face," by Morley, in score with words.

" 158 Exercises in Counterpoint, with the heading " All these are upon the fa-burdon of these playne songes."

" 174 says, "old stuff upon the fa-burdon of the preceding playne songes."

" 189 Canon, "Two in one on the unison, three minims after other"; and yet another interesting note to the following effect, "The rest of these wayes are prickt in my Morley's Introduction."

193 "Pretty wayes for young beginners to look on." There are other headings, such as "Short and long," "Counterpointe," "Indenting Counterpointe," "Turn over three leaves for the rest of the wayes upon the playne song."

" 205 there is written: "The Base parts for two to play"; and again, "The Treble parts for two to play."

I also found the word "good " frequently written over an exercise.

I have come to the conclusion that this very interesting volume contains a collection made by John Redforde, who was Organist, Almoner, and Master of the Choristers of St. Paul's Cathedral from 1530 to 1540 . It doubtless was compiled for his own and his pupils' instruction, but I fail to find in it any church music with organ accompaniment. 
Having disproved the assertion that the ordinary use of the organs in the seventeenth century was to add brilliancy to the vocal music sung by the choir, with the addition of all possible embellishments and florid runs, I shall say a little respecting the statement that "this being objected to by the Puritans, resulted in a blind rage which led to the destruction of Cathedral organs."

On the 13th September, 1696, the Rev. John Newte preached a sermon in Tiverton Church, Devon, on the occasion of the opening of an organ which had just been erected. The sermon was immediately published and evidently widely circulated, for a second edition was found necessary in 1701. The subject of the sermon was "The lawfulness and use of organs in the Christian Church." In the dedication to the Bishop of Exeter I find the following significant phrase: "This (organ) being the first erected in your Lordship's Diocese (out of the City) since the great rebellion had destroyed the use of them in many places." On page II, I read "no wonder that such an unheard of way of reformation, by melting of organ pifes into bullets," \&c. From page 21, I quote the following paragraph :-

"There is, besides the several times when the Psalms are sung, some other proper time customarily made use of for the organ to play some taking Lesson or decent Flourish or other by itself, which goes by the name of Voluntaries; this sort of music is either made just before the service begins, which seems a very proper time for it, to engage the congregation to a serious thoughtfulness and to a civil deportment and behaviour, when they are taking their places, and about to enter upon the most solemn acts of religion in the worship of God. Or it is also used at the end of the Psalnı, before the lessons be read, to strike a reverential awe upon our spirits, and to melt us into a fit temper to receive the best impressions from the word of God. Or lastly, it is used at the end of the whole (service) to take off sone little whispering disturbances, through the levity of some people, and to drown that ungrateful rushing murmur and noise which the stirring of so many people together, at that time of going out of church, must occasion."

Mr. Newte's sermon was attacked in a pamphlet published anonymously, in 1698 , from which some extracts will prove instructive.

It commences by saying " had he confined his beloved music to his own parish, I believe he might have sat down quietly, and have solaced himself with his harmonious pipes, without fear of a contradiction, but he was so ravished with his organical devotion that nothing less would content him than to fill the whole nation with a noise of it." The anonymous author goes on to say: "Singing the praises of 
God with the voice is not only in the judgment of the generality of the Dissenters, but of those of his own church too, a part of natural worship." ... "That the praising of God with instrumental music is a part of natural worship I shall take leave to deny." . . . "The churches received Latin singing, with organs from Pope Vitalian, and from thence began to say Latin mass, and to set up altars with idolatrous images." . . " We must remember that they (organs) were introduced in the times of Popish darkness, and I cannot imagine that Protestants should be the more fond of them, because they were introduced by a Pope." Here there is an honest confession of the reason of the Puritan hatred of the organ - they thought it Popish. "The Cathedral churches, it must be confessed, made use of instrumental music in the worship of God; and we find it in some, and but very few Parish Churches amongst us. But the far greater part of the Parishes have nothing of it. Nay, not one of a 100, perhaps of 500 enjoy this sort of church music." This speaks volumes on the question of the destruction of organs which had taken place in 1698 , not one of 500 churches possessed an organ.

This reminds me to refer to another misleading statement in Notes and Queries by Mr. Davey, who says: "We learn from Pepys, who had never heard the effect of an organ with congregational singing even seven years after the restoration and went especially to Hackney to hear this extraordinary novelty." Pepys' own words under date Sunday, 21 April, 1667,* are: "Took coach and to Hackney Church, where very full, and found much difficulty to get pews, I offering the sexton money, and he could not help me. So my wife and Mercer, ventured into a pew and I into another. That which we went chiefly to see was the young ladies of the school, whereof there is great store, very pretty; and also the brgan, which is handsome, and tunes the psalms, and plays with the people, which is mighty pretty, and makes me mighty earnest to have a pair at our church, I having almost a mind to give them a pair, if they would settle a maintenance on them for it." $\dagger$ Pepys makes no statement that he had never heard organ accompanying the singing, but it would not have been wonderful if he had not heard it, for even thirty years later

* There is a previous entry in the diary on the $4^{\text {th }}$ April. "To Hackney, where good neat's tongue, and things to eat and drink, and very merry, the weather being inighty pleasant; and here I was told at their church they have a fair pair of organs, which play while the people sing, which 1 am mighty glad of, wishing the like at our church at London, and would give f50 towards it.".

$t$ The organ which had been erected in Hackney Church in 1622 had disappeared during the Civil War. A new one was put up in 1666 by a Mr. Roe. The organist was Thomas White; his salary, twel,ty-eight shillings a month. 
not one parish church in 500 possessed an organ. The anonymous writer I have been quoting further says: "The churches which use them are the Popish churches, the Cathedral churches in England, and some very few parish churches." . . . "As for my own part, I am of opinion, that it is with organs in the worship of God, as it is with pictures in churches, a distraction and diversion rather than a help to devotion."

One other quotation must suffice. "Mr. Newte says : Another use and advantage of instrumental music is, that it will prepare us for the being the better edified in Divine service. I must beg his pardon, if I believe not this. But to give instrumental music, a fuller encomium, it will make us, he saith, most knowing, as well as most devout; our reason too, will reap a great benefit by it; and we shall become the more rational, and have a clearer insight into the things above, by being awakened thereto, in the service of God, with stringed instruments and organs. . . . O what a mighty advantage then must it be to persons to dwell near a Cathedral 10 how rational, how enlarged must be the minds of singing men and singing boys be ? Questionless that is the reason so many of the choristers are persons so eminently rational, so eximiously pious and holy."

I have now done with this book, which is full of ingenious argument against the lawfulness of all instrumental music in the Christian Church; the authorities quoted are many and learned, and whatever view we take of the actions of the Puritans in their wholesale destruction of organs we must come to the conclusion that they acted on conscientious religious conviction, and not because of the manner in which the worship music was accompanied by musicians-that accompaniment, as we have seen, was staid and dignified, and the very opposite of brilliant and embellished.

A few final words respecting the singing and accompanying of metrical psalms and hymns. Bishop Gauden, of Exeter (from 1660 to 1662 ), says : " Some have been more at discord with the Liturgy, because they find in Cathedrals and other great churches, the use of music both vocal and organical have been applied to some parts of it ; which certainly is as lawful as any Meeter, Psalmody, Hymnology, or singing to tunes which was never questioned by learned and godly men for lawful in the worship of God, public or private."

This refers to the practice of Psalmody and Hymnody in church in sufficicntly explicit terms-it was allowed by Queen Elizabeth (see her Injunction, No. 49) and sanctioned by Convocation. The Bodleian library has a Sternhold and Hopkins version, published in 1566 , containing the psalms " to be sung of the people together in churches, before and after morning and evening prayer, as also before and after the 
sermon." Again, "The whole booke of psalmes," " compiled by X sondry author! " published by Thomas Est in 1 594, says: "The church tunes are carefully corrected and thereunto added other short tunes usually sung in London and most places of this realme." The editor, Thomas Est, takes credit for putting the tunes into parts, "that each man may sing that part which best may serve his voyce." We may from this presume that he made the parts from an organ part or score. It seems to have escaped notice that the organ part of Tomkins's " Musica Deo Sacra," 1668, contains a set of psalm tunes-here they are- and they present certain peculiarities.The melody or tune is in the upper part-not in the tenor; which was the usual form-and as no voice parts are printed in Tomkins's part-books, we may infer that the tune was sung in unison-the harmonies are full staid and dignified.

Another interesting publication by John Playford is here, it is "Psalms and Hymns in Solemn Musick of four parts on the common tunes to the Psalms in Metre used in Parish Churches." It was published in $167 \mathrm{I}$, and is a most important book. On one side of the folio is the tune, that is the tenor, and the bass; on the opposite side of the folio are the vocal parts-altus, contratenor, and bassus. This gives us in an absolute and concrete form the practice which obtained in 1671 , when an instrument provided the possibility of accompaniment." In the preface we read psalm-singing " had its beginning here in England soon after the Reformation, about the year 1550. In the reign of King Edward the Sixth, Thomas Sternhold of the County of Hampshire Esq., and of the privy chamber to Edward the Sixth, translated thirtyseven of David's psalms into English metre, leaving the rest to be finished by Mr. John Hopkins, William Whitingham, and others, men whose piety exceeded their poetry; yet such as it was it was ranked with the best English poesie at that time. The whole book of Psalms being thus translated into English metre, and having apt tunes set to them, was used and sung only for devotion in private families, but soon after by permission, brought into the churches, being printed and bound up with the books of Common prayer and bibles, with allowance to be sung before Morning and Evening service, and also before and after sermons, and for many years, this part of Divine service was skilfully and devoutly performed, with delight and comfort, by many honest and religious people; and is still continued in our churches, but not with that reverence and estimation as formerly; some not affecting the translation, others not liking the music, both, I must confess, need reforming. Those many tunes formerly used to

Playford in the preface: "The Common tunes are all printed in the Tenor part, and in their proper key, with the Bass under each Tune, as convenient to be sung to an Organ, Lute or Viol." 
these Psalms, are for excellency of form, solemn ayre, and suitableness to the matter of the Psalms, not inferior to any tunes used in foreign churches; but, at this day, the best, and almost all the choice tunes are lost, and out of use in our churches, nor must we expect it otherwayes, when in and about this great City, in above one hundred parishes, there is but few parish clerks to be found that have either ear or understanding to set one of those tunes musically as it ought to be. It having been the custom during the late wars, and since, to choose men into such places, more for their poverty than skill and ability; whereby this part of God's service hath been so ridiculously performed in most places, that it is now brought into scorn and derision by many people." "Herein I have selected all the best and choicest tunes that have been formerly used to the Psalms in metre. The common tunes are all printed in the tenor part, and in their proper key, with the bass under each tune, as convenient to be sung to an organ, lute, or viol." One other rare book I shownamely, "Musick's Hand-maid. New lessons and instructions for the Virginals or Harpsichord," dated 1678. It contains a leaf $I$ have not met with in any other copy, giving "The Tunes of Psalms to the Virginal or the Organ," which, as you will see, are perfectly plain and unornamented. I think I have said enough to refute the extraordinary assumption that the organ accompaniments of the sixteenth and seventeenth centuries were of a frivolous and flighty character. I have not touched upon the organ accompaniments of the eighteenth century - a most interesting periodwhich, perhaps, we may have an opportunity of discussing on some future occasion.

\section{DISCUSSION.}

Thr Chairman.-Ladies and gentlemen, the first thing I ought to do is to apologise for the room we are in. We generally hold our meetings in more luxurious, or, at any rate, larger premises upstairs, in which the lecturer has a better chance of being heard, and any music also. I can only explain that we were obliged to vacate the room for this afternoon as an examination is being held there. It is now my duty to express, in your name, a hearty vote of thanks to Mr. Cummings for the erudite information which he has placed at our disposal. It is really very good of such a busy man as he is to give up the time it must have taken to search through his library, and elsewhere, in order to get together the materials for this lecture. I am sure that I express the 
satisfaction you will all feel when I mention that the University of Dublin has decided to confer on him the distinction of Doctor in Music, honoris causa. (Applause.) Now let me go on to make a few remarks on the paper that has been read to us. They should be very few, because Mr. Davey is here, and the question at issue is really whether he or $\mathrm{Mr}$. Cummings is right as to the particular feature of the organ accompaniment of the Service at a certain period of our history, and it is quite right that he should have an opportunity of getting to work on his argument. Mr. Cummings's allusion to the old organ keys is very interesting. You will find an illustration in "Prætorius" representing the manner of performance on these keys; this well explains the use of the old word pulsator for the person who thumped the keys of the instrument, much as they played on the carillon. The dispute to which allusion has been made seems to have arisen out of a discussion on Gibbons's Service in F. I do not wish to appear as a partisan in the question, but I cannot help thinking that Mr. Davey has mistaken the copy printed by Sir John Stainer, as an old organ voluntary, for the accompaniment which the organist played to the Service itself. With regard to the Anthem which was sung so excellently, I am sorry that the performers, or most of them, are not here for us to return them our thanks-the music reminds us of the madrigals of the period; we know the voices were sometimes assisted with accompaniments. I daresay it would have afforded more variety if we could have had the organ as well as the strings. Still, we have gained a sufficiently clear idea of what the accompaniments were like at that period, and I am sure you will admit there was nothing florid in that. And, in the various books with which Mr. Cummings has dealt, it seems that in all those cases where the organ accompaniments are treated, they are not accompaniments at all in the sense in which we understand the term; they are merely representations of the voice parts. If there was any independent work, such as we hear in accompaniments of the present day, there would be some evidence for what Mr. Davey contends; but from the description of the Mulliner and Redford MSS. I cannot but think there is no florid music to be found there for accompanying the Church music of the day. With regard to that interesting sermon quoted, and the statement that the opening voluntaries were intended to strike a reverential awe, and the final ones to drown the noise of the departing congregation, I think all that is very applicable to the present day; very few stay to hear the final voluntary. The same thing obtains in our theatres. If you go to hear some excellent incidental music, such as the overture to the "Midsummer Night's Dream," now being given in connection with Shakespeare's play at Her Majesty's Theatre, you find the people talk all the 
time and pay no attention to the music. The true reason for the Puritans' hatred of the organ is, I think, that which Mr. Cummings has given. I believe they disliked the organ, not on account of its florid accompaniment, but because it was considered as a Popish instrument, introduced in times when the Church was under the domination of Rome. As for Pepys, the gallant old Pepys, I remember the passage quoted very well; he went in chiefly to see the young ladies, and the organ came in for attention afterwards. Of the attacks which were made upon Church music and Church organs I know Mr. Cummings could have given you many examples. There is an enormous number of pamphlets by the Puritans, all expressing their detestation of Church music and organs; but none of them, so far as I know, advance the argument that the accompaniments are frivolous and only useful in the way of allowing the church organist to show off his skill. I will now ask Mr. Davey to favour us with his remarks or criticisms on what has been said.

Mr. Davey.-Mr. Chairman, ladies, and gentlemen, I am afraid I shall get a name in this society as a maker of discord, for at our last meeting we got into a discussion about myself. After the discussion that I had had with Mr. Cummings and another well-known contributor to Notes and Queries, I was quite prepared to find that he would speak very considerably upon myself to-day ; but I did not know he was going to make his paper bear almost entirely on the particular question. However, I do not despair of convincing him. At the same time I must ask you to remember that in many cases we have to go on internal evidence and not on direct statements. There is one case I must take with regard to the beautiful anthem by Gibbons that you have heard, and also with regard to Tomkins's "Musica Deo Sacra." I wrote from memory; that was why I used the expression, "if I remember rightly." In the British Museum there is the vocal music, but no organ part. Now let us look at the anthem of Gibbons and the "Musica Deo Sacra," particularly with regard to the remark that there were no grace-notes. It was not the custom to write any gracenotes. Even a century later Bach was strongly blamed by the critics of his day for introducing the innovation of writing in the grace-notes.

Mr. Cummings.-I purposely refrained referring to the next century so as not to go beyond the scope of the subject.

Mr. DAVEY - In all the older music grace-notes were custom. arily added by the performer. You can find that from Couperin, who was before Bach. [Mr. Cummings.-Almost contemporary.] But at any rate there is no distinct external proof that grace-notes were not added then as they were later.

Mr. Cummings.-But you have to prove that they were added. 
Mr. DAvgy.-However, I can waive all that. To begin with, I will give you an account of what music was up to the Civil War. The English part has not been up till recently much discussed or brought out. The German history of organ playing has been. But it is only now that they are beginning to recognise how they owe their school to the English school. I want to show you what their organ playing was which has been worked out as regards the history of German music, and of which we have printed documents which we have not in England. Here is an extract from the very elaborate and able article on Samuel Scheidt in the Appendix to "Grove's Dictionary": "From 1570 to about 1620 , organ playing in Germany almost entirely consisted in what was known as 'koloriren,' the art of 'colouring ' melodies sacred or secular by the inserting of meaningless passages, all framed on one and the same pattern, between each note of the melody." Ritter's "History of Organ Music" gives full particulars of the "Koloristen," whom Ambros most justly calls "tasteless barbarians." By his "Tabulatura Nova," which appeared in 1624 , Scheidt inaugurated a better style, and laid the foundation of the great German school which culminated in Bach. The third part of this work is the most important; and again, quoting Grove : " Both by the choice of pieces, and the manner in which they are arranged, it gives us an insight into the way in which the organ was very frequently employed in the church services of those days. It was not then generally used to accompany or sustain the voices of the choir or congregation, but rather to alternate with them." That is, it would play interludes between each verse of a canticle or psalm, and it also would respond to the priest's intonation at the altar, giving a polyphonic or ornamented version of the plain-chant. Instances of this occur both in Scheidt's "Tabulatura Nova" and in the contemporary works of Frescobaldi, the greatest Italian organist. But in 1650 , twenty-six years later, Scheidt published another work, "which shows a different conception as to the use of the organ in the services of the church, and probably marks a change which was then going on gradually in the practice of the Lutheran Church. The congregational singing of metrical hymns was gradually superseding the older liturgical music, and the organ had more and more to surrender its independence to accommodate itself to the simple accom. paniment in four-part harmony of the melodies of these hymns." According to A. G. Ritter ("Zur Geschichte des Orgelspiels," p. I12), the Lutheran congregational singing became so feeble during the second half of the sixteenth century, that at last it could not exist without help, and accordingly the organ was brought in to assist. After the Reformation, the German organ music had been of the worst possible character. 
Hermann Finck, in his "Practica Musica" (1556), had reprobated it in the strongest terms, and it indeed consisted only of very poor embellishments of sacred and secular tunes. You have heard how it altered through Scheidt, and during the seventeenth century it continually.improved, till all was ready for the genius of J. S. Bach. Yet even Bach has left, besides choral fantasias, also interludes to congregational singing. One is quoted at the end of Spitta's exhaustive biography. Now were, at first, these matters better in England? In some respects they certainly were. To begin with, the English execution was very much superior to anything known on the Continent, and real part-playing was practised. Nevertheless, the style of performance was not what we should call suitable for sacred music, and, above all, it seems to have been not congregational. I have specimens here which I have copied from four MSS. of the sixteenth century, and they show that the organ music was florid, as the vocal music was. I have much older music here, perhaps of the fourteenth century; but I will show that later. I will begin with passing round specimens from Addit. MS., 15,233. (Pieces I had brought were from Royal MSS., App. 56, the Redford MS., completed by Tomkins, the Mulliner MS., and Addit. MS., 15, 233.)

Mr. Cummings. - I say these did exist, but they are voluntaries and exercises and were never intended for accompaniments to the service. Mr. Davey has quite mistaken my meaning. If he has treated this as he has treated the Mulliner MS., what is his description worth if he had no better acquaintance than that with it ?

Mr. Davey.-I wrote to Notes and Queries that I was sorry for the mis-statement concerning Gibbons's Service. Mr. Cummings had corrected me, and I said I was sorry I had make a mistake. I do not know what more I could do.

The Chairman. - Can you produce any evidence that that was sung with voices?

Mr. DAVBY.-I have here a specimen of the Redford MS. in which there are eight different settings of the Gregorian Tones.

Mr. Cummings. - That is a copy I have taken down. It is exercises on the plain-song.

Mr. Prendergast.- There are no catchwords here. All organ accompaniments have these. It is simply called $\mathrm{Te}$ Deum; that is all.

Mr. DAVEY.-I wish to pass you this piece, that you may see for yourselves where they are arranged as accompaniments or where somebody amused himself with arranging them as instrumental solos. The dislike to organs was not confined to the Puritans, unless we use the term Puritans to represent the Low Church party generally. There was a man who had the organ taken out of his own church; that was George 
Abbot, the Archbishop of Canterbury. He had the organ removed from Lambeth Palace Church. The reason was that in those days, as I hold, organs were not used to accompany the Psalms." Peter Smart, who was prebendary of Durham Cathedral, was imprisoned for objecting to the re-introduction of organs and the sweet tone of Psalms. As he says: "Immediately that Bishop Neale was appointed in 1627 psalm-singing was put down and singing to the organ substituted." The homily of the Place of Prayer bids all churchmen to rejoice that organs had been put down. The time when organs were put down was mainly the opening years of Queen Elizabeth's reign. In a recent issue of Musical News you will find an account of the organ at Coventry; there is another about the great church organ at Leicester, in the present number of the Musical Herald; and a MS. among the Royal MSS. at the British Museum written in the time of James I. says the same thing-that about ${ }_{1567}$ the organs were pulled down and the pipes sold to make pewter dishes. The Genevan disciples who then ruled the Church had a very strong objection to this organ playing, which I believe consisted of intermezzos. I should like, ladies and gentlemen, for you to examine this book of mine; it contains many pieces that I have copied from the Mulliner and other MSS.

Mr. Prendrrgast.-I have looked carefully through that volume, and it seems to me that intrinsically they all look like voluntaries. There are no marks of words anywhere. The words Te Deum are written at the beginning. Almost all organ copies that I have seen have "We knowledge" (not acknowledge). I think that all those that have been produced are written to be played apart from the voices.

The Chairman.-I should be very unwilling to stop a discussion if I thought it was possible to convert either of the disputants; but I do not suppose it is possible for either of these gentlemen to convince the other. The question seems to be whether these florid arrangements cited were meant to be accompaniments to the service, or were merely arrangements for instrumental solos. The examples Mr. Davey alleges do not seem to me to have been intended for accompaniment while the music was being sung. I could point out to you that in the accompaniments of the time there was always a catchword to show where the voices came in; it is significant that they do not exist in these examples. Mr. Davey has now gone through $\mathrm{Mr}$. Cummings's particular case. Unless he has anything more to add, I would, before the meeting closes, ask Mr. Vignoles to make an announcement to you.

Mr. VignolBs. - I have a message connected with your Association which I am sure will be grateful to all of you.

"See also the "Sammelbãnde" of the Internationale Musikgesellschaft. Pp. 420-29. 
It is from Mrs. Pole, the wife of, I think, one of the oldest of your members, and, perhaps, the oldest Doctor of Music in England. He has been at death's door for weeks, but is now slowly recovering. He wishes it should be known how thankful he and his family are that a man who has been ill for months, and has just turned eighty-six, is still spared to be amongst the living musicians of England.

The Chairman.- I am sure we are all very glad to hear what Mr. Vignoles has said about Dr. Pole, one of our most distinguished members, to whom the University of London owes its faculty of music. Dr. Pole, old as he is, is not the oldest graduate of music in England. Mr. Kellow Pye took the Bachelor's degree at Oxford fifty years ago. It only remains for me to call on you to pass a very hearty vote of thanks to Mr. Cummings at the end of this long and somewhat discursive meeting, and I am sure that when we read all this in our Proceedings we shall be still more enlightened by what we have heard to-day.

The vote of thanks was passed unanimously. 


\title{
MUSICAL ASSOCIATION.
}

\author{
Fune 12, 1900.
}

The Chairman (Mr. Prendergast).-Before we proceed to the business of this evening I have to propose that we pass a very cordial vote of sympathy to Lady Grove on the death of Sir George Grove, who has been a distinguished member of this Society since its foundation.

Mr. Southgatg. - This is not an occasion to discourse on the truly wonderful work, or to eulogise the merits of the late Sir George Grove. He was an original member of this Association, and from time to time he has rendered us considerable service. He brought many members-some who have gone to rest, but who have read papers of great interest. He himself has read valuable papers here, and has often taken part in the discussions. We have all sustained a severe loss in his death, and I beg to second your proposition.

The resolution was passed unanimously. 